\title{
THE AGRICULTURE SECTOR IN WESTERN BALKANS - SOME CHARACTERISTICS OF DEVELOPMENT
}

\author{
Radmilo Nikolić', Aleksandra Fedajev², Vidoje Stefanović3 ${ }^{3}$, Silvana Ilićc
}

\begin{abstract}
Summary
Agriculture in the Western Balkan countries has the significant role. It has the highest share in GDP right after the industry. However, transition processes as well as the breakup of former Yugoslavia caused serious stagnation in this economic activity in almost all its areas. Measures and actions taken in order to make an unfavourable situation in this sector better, did not bring results which had been expected. The recovery of agriculture is still slow and faces numerous obstacles. The aim of this paper apropos is to analyse the role of this sector in Western Balkan economies by using the multi-criteria analysis or more precise PROMETHE GAIA methodology. Obtained results indicate that agriculture sector has the most significant role in Albanian economy, followed by FRY Macedonia, Bosnia and Herzegovina, Serbia, Croatia and, at the very end, Montenegro.
\end{abstract}

Key words: agriculture, Western Balkans, economic development, multi-criteria analysis.

JEL: Q10, Q16,

\section{Introduction}

At the beginning of XXI century, the European Union formulated the name of the region Western Balkans, to indicate the group of Balkan countries which are not members of the European Union, but strive to become the members. In that sense, this region consists of

1 Radmilo Nikolic Ph.D., Full Professor, University of Belgrade, Technical faculty in Bor, 19210 Bor, Vojske Jugoslavije Street no. 12, Republic of Serbia, Phone: +381 6384274 85, E-mail: rnikolic@tt.bor.ac.rs.

2 Aleksandra Fedajev Ph.D., Assistant Professor, University of Belgrade, Technical faculty in Bor, 19210 Bor, Vojske Jugoslavije Street no. 12, Republic of Serbia, Phone: +381 694833364 , E-mail: afedajev@tt.bor.ac.rs.

3 Vidoje Stefanovic Ph.D., Full Professor, University of Nis, Faculty of science and mathematics, 18000 Nis,Visegradska no. 33, Republic of Serbia, Phone: +381 6422970 77, E-mail: widojes@yahoo.com.

4 Silvana Ilic, Ph.D, Associate Professor, John Naisbitt University, Faculty of Management in Zajecar, 19000 Zajecar, Park suma Kraljevica nn., Republic of Serbia, Phone: +381 6550555 11, E-mail: silvana.ilic@,fmz.edu.rs.

EP 2017 (64) 1 (275-293) 
countries of former FR Yugoslavia (excluding Slovenia) and Albania (Fedajev, 2015). In the mid-2013 Croatia has become the member of EU, but many authors still include this country in the analysis of this region, as a good role-model for other states.

Agriculture has its long tradition in the Western Balkans. It represents one of the oldest activities in human society, being one of the predominant occupations of the population even today. For many years agriculture had been the main occupation of the population in this region, but, over time, it was overtaken by the industry (Nikolić, 2012). Nevertheless, agriculture still brings a significant contribution to economic development of the countries in this region. Historically, agriculture in the Western Balkans was very obsolete and underdeveloped during the first half of XX century. So, it could not provide enough food for the population nor raw material for already undeveloped food industry as well as other processing industries. It had natural character, with only one-third of the production realized through the market. During the Second World War modest agricultural capacities were largely destroyed and devastated. This particularly affected agro-industry causing its severe collapse.

After the war, special attention was paid to food production. It became one of the priority activities in economy. By taking various actions and measures its accelerated development was being boosted even more. The achieved effects were obvious in all aspects of production (The Federal Statistical Office, 1986). The average annual agricultural production growth rate on the territory of former Yugoslavia (now independent states: Slovenia, Croatia, Bosnia, Montenegro, Serbia and Macedonia) in the period from 1945 to the 1990s was close to $3 \%$, although it had always been lower than the industrial production growth rate. The total agricultural production was three times larger, with significantly increased livestock and altered cattle breeds; fruit orchards and vineyards were expanded, and the application of modern techniques and technologies, along with agro-technical measures in the production, enabled increase in yield of the most important crops from 1 up to 1,5 times. Due to afore mentioned progress the following production results were visible in the mid 80's: this region produced $1 \%$ of total wheat production in the world; $2 \%$ of corn; $2.4 \%$ of sugar beet, $1.1 \%$ of all kinds of meat $(0.8 \%$ of beef and $1.4 \%$ of pork) as well as $1 \%$ of cow milk. The share in European production of food was much more significant (Nikolić, 1999). At the same time, Albanian agriculture also recorded a remarkable progress. Its development was directly controlled by the state.

However, since the 80's, the growth rate in agricultural production in former Yugoslavia had been slowing down. Stagnation was especially noticed in livestock production, mainly in the private sector. Such conditions were further worsened by the events related to the breakup of the country in the 90 s, causing consequences such as breakup of unified market, war devastation of agricultural and agro-industrial resources, limitations in the export of agricultural and agro-industrial products and the import of the necessary input for their production, insufficient application of modern techniques and technologies, decrease of domestic demand due to the economic crisis and downfall of life standard of the population. Agriculture suffered yet another decline, although even in such circumstances, it managed to endure the greatest burden of the crisis which the economies in the region had been affected by. Meanwhile, in Albania, the agricultural 
production growth had continued with slight oscillations. Modest agricultural capacities were still unable to feed the population, so the necessary food was provided by import. Albania was famous for production and export of tobacco, alcoholic beverages and wool. (Marković,1989).

Transition processes in Western Balkan economies which also included reforms of agriculture sector started in the early 90's (Stojanović, 2005). The aim was transition from a non-functional and a non-efficient system into a modern, open and diverse market based economy (Zec, Živković, 1997) which would create the conditions for overcoming the crisis as well as establishing long term sustainable development. For agriculture, it meant creating favorable ambience for market economy, thus, greater efficiency in business activities. During the 90's, transition processes were very slow followed with difficulties and uncertainties. At that time the political situation in the region was unstable which considerably contributed to the situation. (Uvalić, 2011). Besides, no one was ready for substantial and comprehensive changes, not even the authorities. Hence one can say that the true reforms began in the early 2000's, with radical changes in all aspects of both economy and society. Some countries, created after the breakup of Yugoslavia, had certain advantage at the beginning of transition, due to reforms they had performed earlier, which transformed them in a kind of "semi market oriented system" (Nikolić, Fedajev, Riznić, 2013). However, delay in conducting reforms in the 90s as well as many obstacles following the whole process on one hand, and faster progress in the rest of transitional countries, especially Central and Eastern European countries, on the other, caused that even today Balkan countries are in the last position at the transitional countries' ranking (Kovačević, 2011). The exception is Croatia which successfully managed to complete the reforms and in 2013 it joined the European Union. Even Albania, which had unfavourable starting position, managed to reform certain economic areas faster than the countries formed after the breakup of Yugoslavia.

In agriculture, transition processes were carried out in accordance with the changes of the general economic situation in a country. Due to the fact that most of the agricultural land in former Yugoslavia was owned by private owners, the problems which occurred during the ownership changes in state owned companies, were being avoided. Namely, many of large agricultural enterprises went bankrupt after privatization, while some of them are still owned by the state. On the other hand, Albania successfully managed to privatize agricultural land. It also achieved an overall progress in agriculture, thus achieving a fairly high economic growth rate during the nineties (Rikalović, 1999).

This paper is focused on the investigation of agriculture role in Western Balkan economies in the period between 2001 and 2012, i.e. on the period when the economic reforms in these countries were most intensive. In order to get a more complete insight into implemented changes and reforms so far, a multi-criteria analysis was applied, the PROMETHEE GAIA method to be more precise. Usage of this method enabled the ranking of the countries based on some important indicators that reflect the role of agriculture in the economy. 


\section{Methodology}

In order to perform a comparative analysis of the importance of agriculture sector for economic development, multi-criteria analysis has been applied. The aim of multi-criteria analysis is to rank numerous alternatives from best to worst, based on a large number of opposing criteria. One of the most commonly used methods of multi-criteria analysis is PROMETHEE GAIA method, developed by Brans, Vincke and Marshal during the late XX century (Brans, Mareschal, Vincke, 1984,Brans, Vincke,1985). The PROMETHEE GAIA methodology was conducted on the biases of data on gross value added in agriculture (\% GDP) from World Bank database, employment in agriculture ( $\%$ of total number of employees) from national statistical offices, balance of agriculture trade and net production index number from FAOSTAT in 2012, as an end of the period.

\section{PROMETHEE GAIA methodology}

In recent years, a large number of methods for decision support have been developed in order to facilitate finding the best compromise solution. One of them is certainly the PROMETHEE method developed by Jean-Pierre Brans and Bertrand Mareschal. This is one of the newest methods in multi-criteria analysis, and it is known as one of the most effective and the simplest in this field. The advantages of this method lie in the way of structuring the problem, in the amount of data that can be processed, the possibility of quantifying qualitative data, good software support and presentation of results (Obradović, Fedajev, Nikolić, 2012).

The PROMETHEE method is an adequate method for solving problems whose aim is multi-criteria ranking of final set of alternatives (in this case Western Balkan countries) based on a number of criteria which need to be maximized or minimized. For each observed alternative it calculate its value expressed in level of preferences. Thereby, each alternative is evaluated based on the two preference flows. Positive preference flow $\varphi+$ (P) indicate how much is given alternative better than the other (according to all criteria). Accordingly, the higher this preference flow is, the alternative is better. The negative flow of preference $\varphi-(\mathrm{P})$ indicates how much a given alternative is worse than the rest, and therefore if this flow is lower, the alternative is better. After that, the PROMETHEE method accounts net preference flow $\varphi(\mathrm{P})$ as the difference between these two flows (Brans, Mareschal, Vincke, 1984, Brans, Vincke, 1985).

On the bias of such calculated net preference flow, final ranking of alternatives is performed, from the best one, with the highest net preference flow, to the worst one, with the lowest net preference flow. To calculate mentioned flows, PROMETHEE method requires the specification of appropriate parameters for each criterion (Brans, Mareschal, Vincke, 1984; Brans, Vincke,1985):

1. Direction of preference, minimizing or maximizing;

2. Weight coefficients, indicating the importance of certain criteria;

3. Adequate preference function, that converts the difference between the two alternatives in the level of preference, which ranges from 0 to 1. In PROMETHEE 
methods following preference functions are available: Linear, Usual, U-shape, V-shape, Level and Gaussian;

4. Preference threshold $(\mathrm{p})$, which represents the minimum deviation that decision maker considers important for the decision making;

5. Indifference threshold (q), which represents the maximum deviation that decision maker considered irrelevant for the decision making.

After defining parameters, PROMETHEE methodology is used, which consist of next steps (Behzadian, Kazemzadeh, Albadvi, Aghadasi, 2010):

1. First, deviation based on comparison of pair of alternative is calculated

$$
d_{j}(a, b)=g_{j}(a)-g_{j}(b)
$$

Where $\operatorname{dj}(a, b)$ represent differences between the value of alternative $\mathrm{a}$ and $\mathrm{b}$ according to every criteria.

2. After, the chosen function of preferences is used:

$$
P_{j}(a, b)=F_{j}\left[d_{j}(a, b)\right]
$$

Where $\mathrm{Pj}(a, b)$ represents preferences alternative $a$ for each alternative $b$ within every criteria, as a function of $d j(a, b)$.

3. Further, the general index of preferences is calculated:

$$
\forall a, b \in A \pi(a, b)=\sum_{j=1}^{n} P_{j}(a, b) w_{j}
$$

Where $\pi(a, b)$ stands for weighted sum $\mathrm{P}(a, b)$ for each criteria, while $w_{j}$ stands for weighted $j$ criteria coefficient.

4. Then, the positive and negative course of preferences are calculated:

$$
\begin{gathered}
\varphi^{+}(a)=\frac{1}{m-1} \sum_{x \in A} \pi(a, x) \\
\varphi^{-}(a)=\frac{1}{m-1} \sum_{x \in A} \pi(x, a)
\end{gathered}
$$

Where $\varphi+$ represents positive and $\varphi$ - negative preferences values for each alternative.

5. Finally positive and negative courses of preferences are used to calculate net flow of preferences and rank alternative:

$$
\varphi(a)=\varphi^{+}(a)-\varphi^{-}(a)
$$


Where $\varphi(a)$ stands for net course for each alternative.

On the bias of $\varphi(a)$ value the countries are ranked from best to the worst, having in mind all observed criteria.

\section{Role of the agriculture in economy}

Bearing in mind that all Western Balkan countries are transition economies and that they have favourable geographic and climate conditions for agricultural production, their development is still mostly dependent on agriculture sector performance. Most of them have significant share of agriculture employees in total number of employees, the agriculture production records relatively high growth rates (contributing to the level of total production in country), foreign trade of agriculture products enables the reduction the trade deficit in these countries (which is significant problem in most of transition economies) and the gross value added in agriculture contributes greatly to the creation of GDP.

But, these countries, also face significant limitations in the agriculture development, like fragmented farm-holdings, low productivity, the use of outdated techniques and technology, low level of investments (caused by insufficient investment capacities and lack of interest for investments), low level of business activities, undeveloped infrastructure, low income and lack of alternative types of financing (Stojadinović Jovanović, Dašić, 2015). Depending on the extent to which they have managed to reduce the effect of these factors, the Western Balkan countries have different performances of their agricultural sector.

\section{Employment}

Despite an evident deararization during the second half of the last century, a large part of the population in the Western Balkans was still employed in agriculture. This situation was largely retained, even in the period of transition, although it had been expected that some of the workers from industrial companies which went bankrupt, would return to their villages and re-engage themselves in agricultural production.

Figure 1. Employment trends in agriculture, industry and other sectors in 2012.

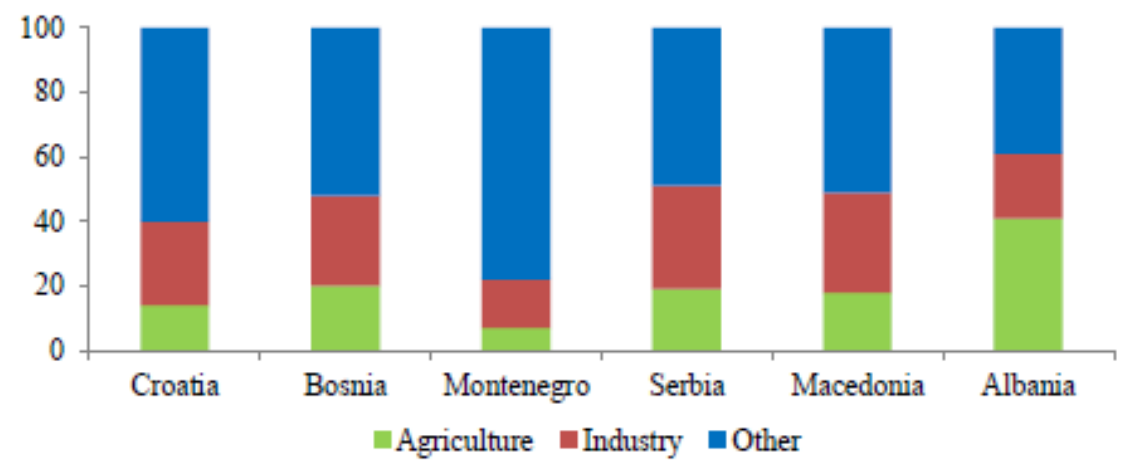

Source: Author's calculations based on data from National Statistical Offices of observed countries. 
It is obvious from the Figure 1 that Albania has a very high employment in agriculture, 41.5\%. This defines the country as agricultural. After Albania come Serbia and Bosnia with $20 \%$ of agricultural population. Macedonia follows, with $17.3 \%$, Croatia with $13.7 \%$ and Montenegro with only $5.7 \%$ of the total number of employees. In the EU that figure is around $6 \%$.

Particular problem is the age structure of employees in agriculture, due to the dominance of the elderly population. That is particularly true for Montenegro (Božović, Đurašković, 2014). The young are less motivated to stay in the village and work in agricultural production. Hence, year after year, many villages located south of the Sava and Danube rivers, are becoming uninhabited and huge complexes of agricultural land are being abandoned and overgrown with weeds.

\section{Trends in Agricultural production}

Available resources for development, position and role in the economic system are the main preconditions for the agriculture development, and therefore for the development of both volume and structure of its production. Therefore, the achieved level of agriculture production significantly varies in Western Balkan countries.

\section{Croatia}

Croatia represents one of the larger agriculture producers in the region, right behind Serbia. It has solid development resources. Crops are dominant in plain areas, orchards and vineyards in hilly areas, livestock production in the mountains while Mediterranean cultures are present on the coast. In the structure of total agricultural production, in 2012, crops production prevailed with $63 \%$ and farming had the leading position. In livestock production - pig breeding was dominant.

Figure 2. Production Indices - Net Production Index Number (2004-2006 = 100), 2001 - 2012

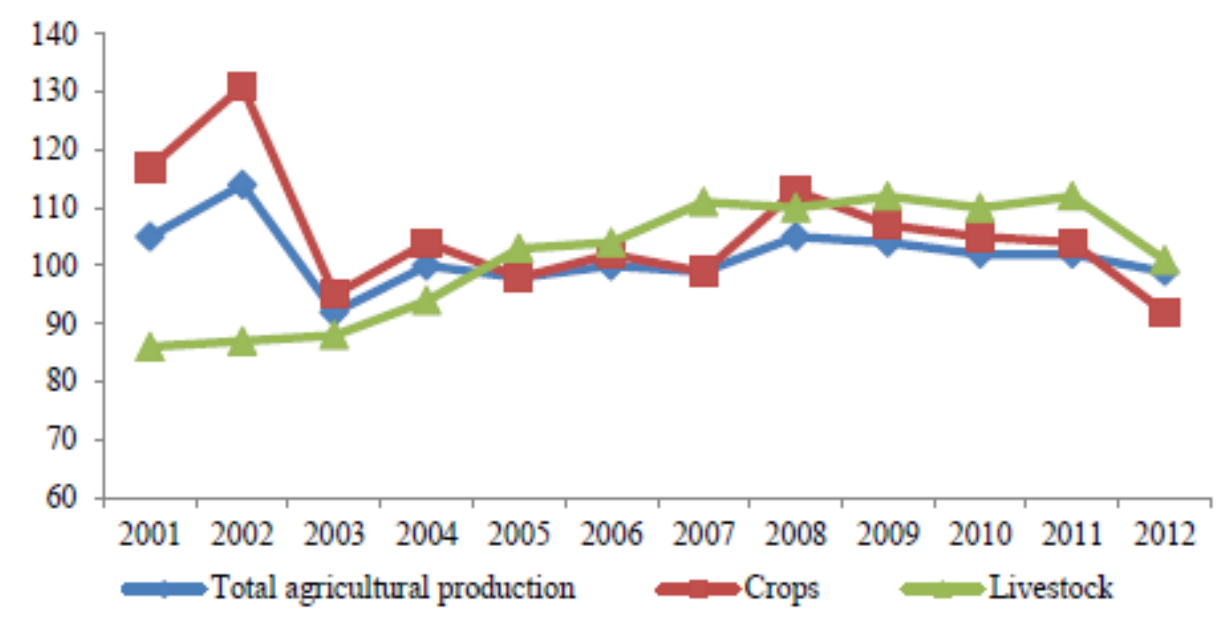

Source: FAOSTAT database. 
After certain stagnation came a period of slow growth in the total agricultural production. Crops production had significant oscillations while livestock production showed a more stable growth. In the production of crops, cereals were predominant with presence of vegetables, industrial and forage plants as well.

\section{Bosnia and Herzegovina}

Bosnia and Herzegovina is mostly mountainous country with some parts of hilly areas and the plains in the valley of rivers. These resources determined agricultural development of the country.

Figure 3. Production Indices - Net Production Index Number (2004-2006 = 100), 2001 2012

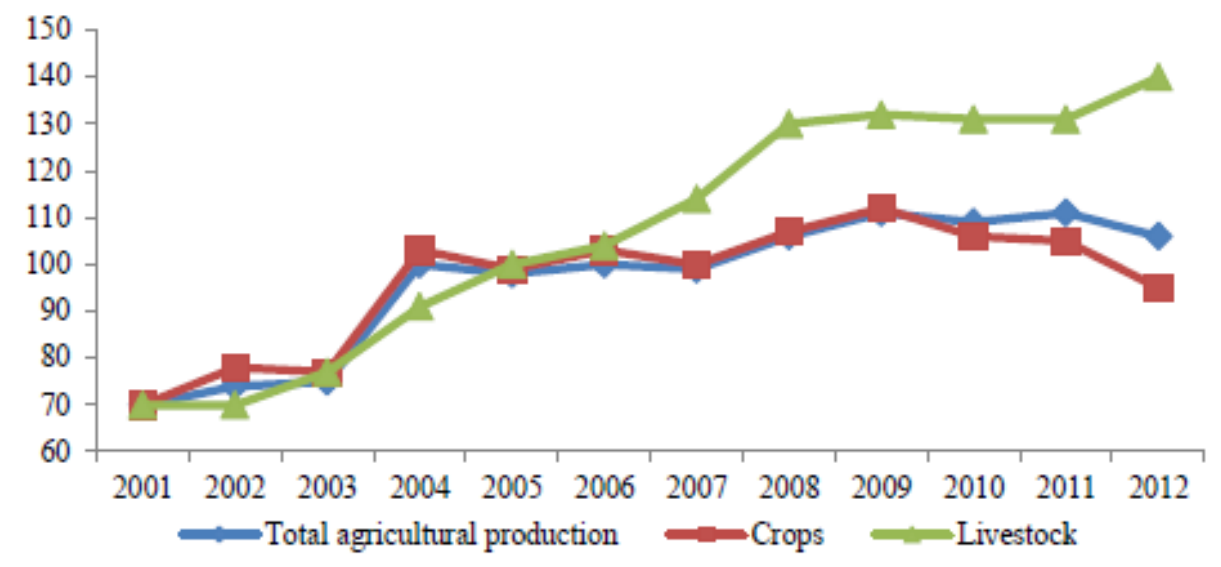

Source: FAOSTAT database.

The total agricultural production value had a trend of constant growth, where livestock production growth was pretty faster, while crop production varied a lot.

\section{Montenegro}

Besides tourism, as the leading economic sector, Montenegro paid a certain attention to agriculture production. Considering the available resources, the production level was mostly modest. Agriculture held a 9\% share in GDP, or 18\% together with food industry. 
Figure 4. Production Indices, 2001 - 2012 - Net Production Index Number (Serbia and Montenegro 2004-2006 = 100, Montenegro $2006=100$ )

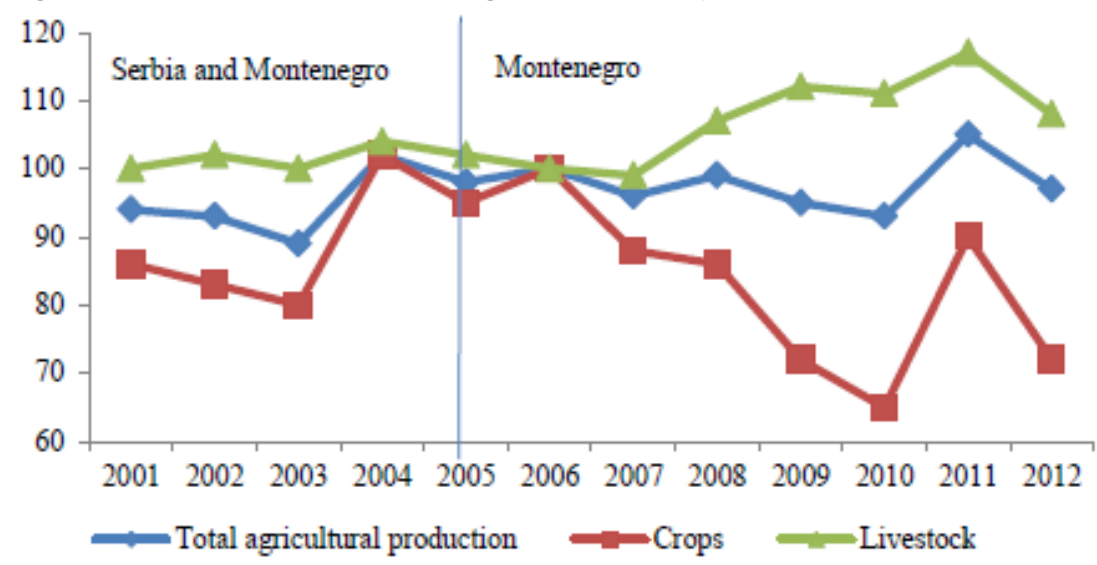

Source: FAOSTAT database.

The total agricultural production was increasing slowly. The production of crops was increasing more rapidly, but with oscillations. Its share in the structure of agricultural production reached $63 \%$. At the same time, livestock production had rapidly been decreasing.

\section{Serbia}

Serbia has very favorable conditions for the development of various agricultural production segments. Fertile plains, hilly areas with vast meadows and pastures, suitable climate and dense network of river flows are the basic natural amenities of this area. Moreover, Serbia has long tradition of farming. However, these favorable agriculture development resources were not valorised adequately. Since the 80 's, and especially 90 's, there had been a trend of decrease in production in many sectors of agriculture. During the intensive transition, after 2000, there had been a certain increase of production with occasional oscillations. Livestock production had firmer stability, while the production of crops recorded its ups and downs. Two major downfalls of crop production occurred in 2007 and especially in 2012. A change in the structure of production is one of the specific features of Serbian agriculture. Previously dominant livestock production lost its position in favor of crop production. 
Figure 5. Production Indices, 2001 - 2012 - Net Production Index Number (Serbia and Montenegro 2004-2006 $=100$, Serbia $2006=100$ )

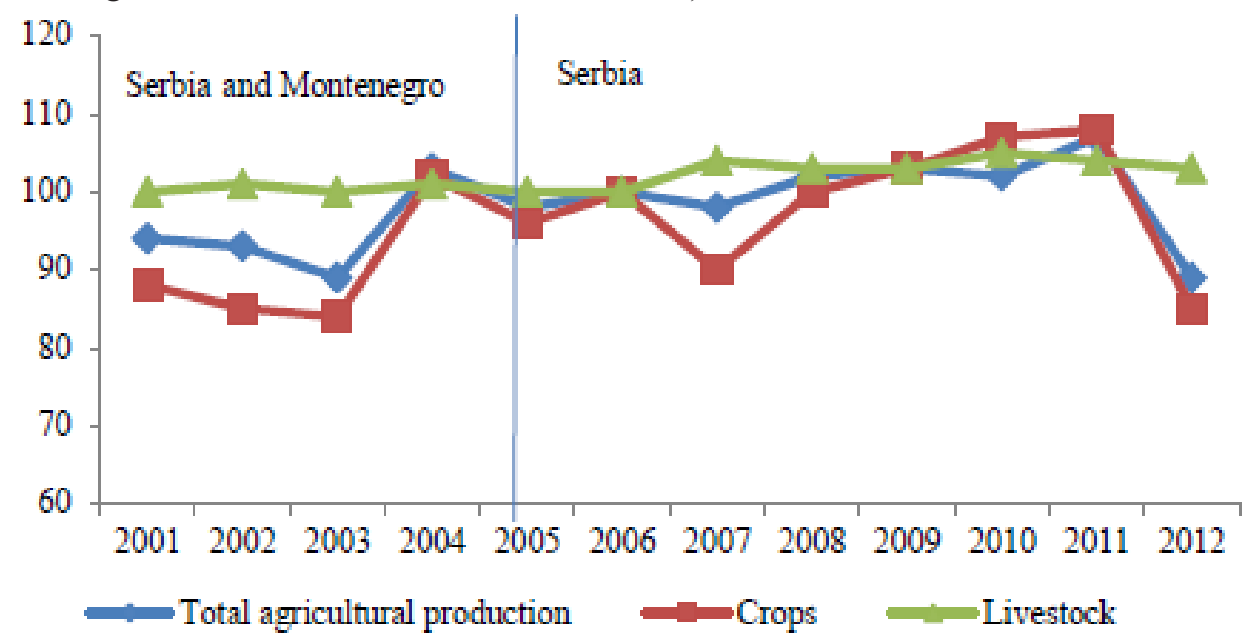

Source: FAOSTAT database.

In recent years, the situation in livestock production has been slightly better. Wheat production is dominant in the structure of crop production. Also, most of agricultural land is covered with vegetables, industrial and forage plants.

\section{Macedonia}

Agriculture has an important position in the economy of Macedonia. It has many natural advantages, such as favourable relief, climate and water resources. Traditionally, Macedonia has always been well known for the production of quality vegetables, fruits and grapes.

Figure 6. Production Indices - Net Production Index Number (2004-2006 = 100), 2001 2012

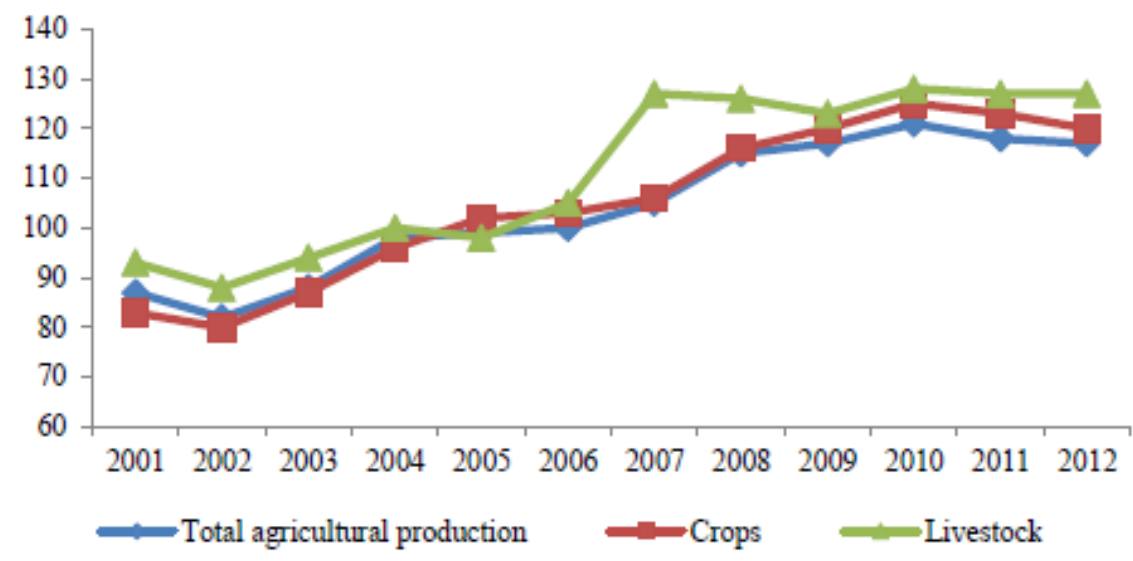

Source: FAOSTAT database. 
The total agricultural production has had a trend of constant growth, mainly due to livestock production, which had a significant increase in the observed period. Crop production also recorded increase.

\section{Albania}

Albania pays special attention to the development of agriculture. The area is convenient mainly for livestock production, while river valleys and sea coast are suitable for growing crops and fruits.

Figure 7. Production Indices - Net Production Index Number (2004-2006 = 100), 2001 2012

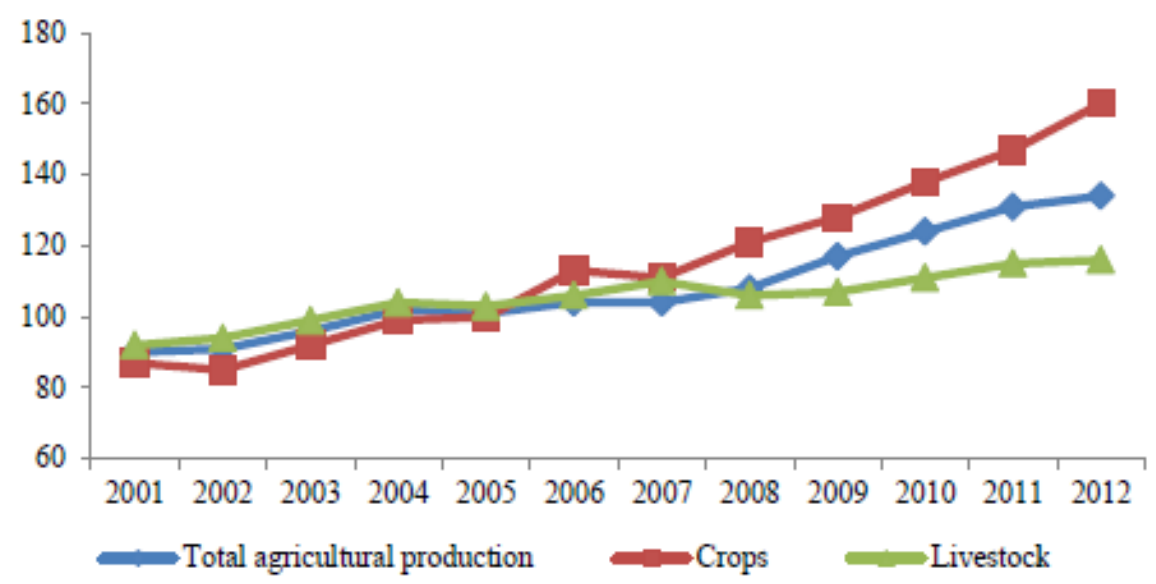

Source: FAOSTAT database.

After a strong downfall at the beginning of transition processes, Albanian agriculture production has recorded significant growth since 2001, both in crops and livestock.

\section{Foreign trade of agricultural products}

After meeting their own needs, the countries of Western Balkans exported a certain share of their agricultural and food products. During the observed period, trade was mostly realized between Balkan countries themselves, through CEFTA agreement. The greatest exporters of agro-food products in the region are Serbia, Croatia and Macedonia, while Croatia and Bosnia are the greatest importers. Serbia is the only country in the region with a surplus in the agriculture products balance of trade. 
Figure 8. Agriculture and food industry trade, 2001 - 2012

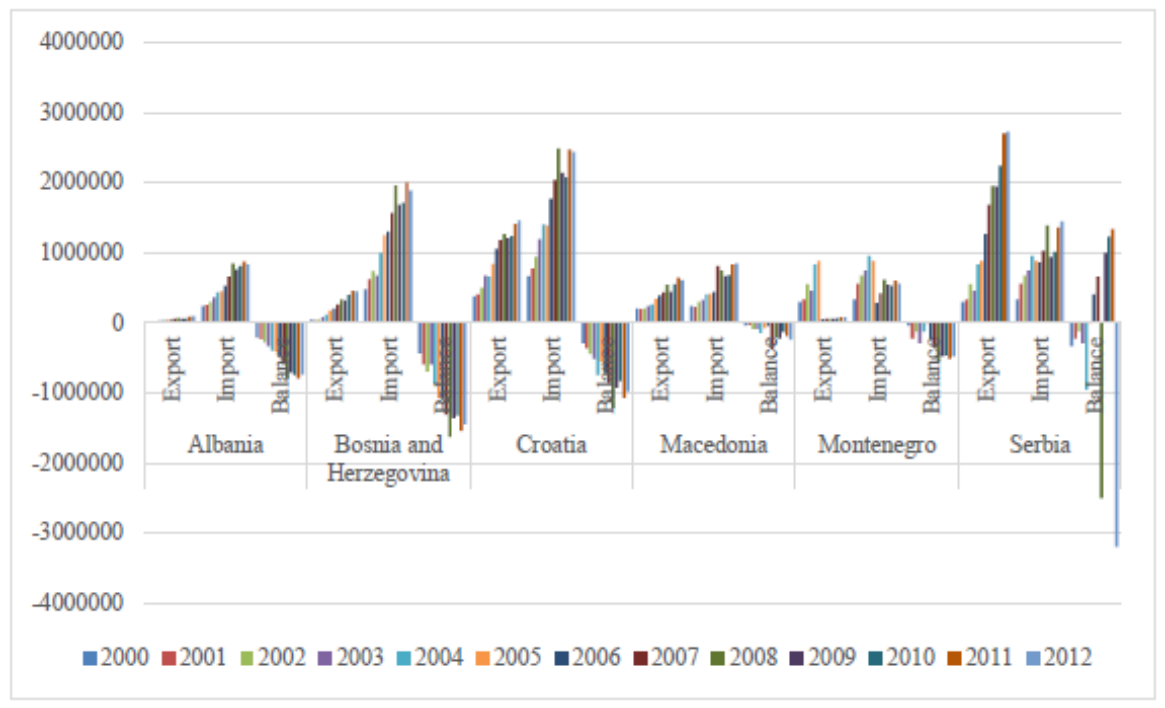

Source: FAOSTAT database.

In 2012, the total export of agro-food products from the Western Balkan countries reached 5.369.183.000 USD, and at the same time the import reached 8.139.197.000 USD. Serbia is a leader in export, with 2.7 billion USD, followed by Croatia (1.4) and Macedonia (0.64). Croatia is the leading importer, with 2.5 billion USD worth import in 2011, followed by Bosnia and Herzegovina, with approximately 2 billion USD.

\section{Gross value added}

Economic crisis, caused by the breakup of Yugoslavia in the 90's, negatively influenced the entire economy of the region including agriculture as well. Unified market fell apart, former republics became independent states, previously established trade arrangements was reduced or terminated, financial sanctions and devastation caused by civil war had considerably diminished agricultural funds. Furthermore, during transition, a majority of large agricultural concerns were closed, along with many small agricultural cooperatives which were holders of agricultural production. Even in such circumstances, agriculture, even though carrying the burden of economic crisis, managed to survive. Over time, with improvements in political and economic ambience in the region, the situation in economy as well as in agriculture became more favourable. The volume of production increased, foreign trade and life standard of the population started to improve. However, due to the accelerated development of other economic areas, such as industry and service sector, the share of agriculture in GDP had been constantly decreasing. In 2012, Albania has the highest contribution of agriculture in creation of gross added value among countries in the region, reaching $22 \%$. 
Figure 9. Gross value added in agriculture (\% of GDP)

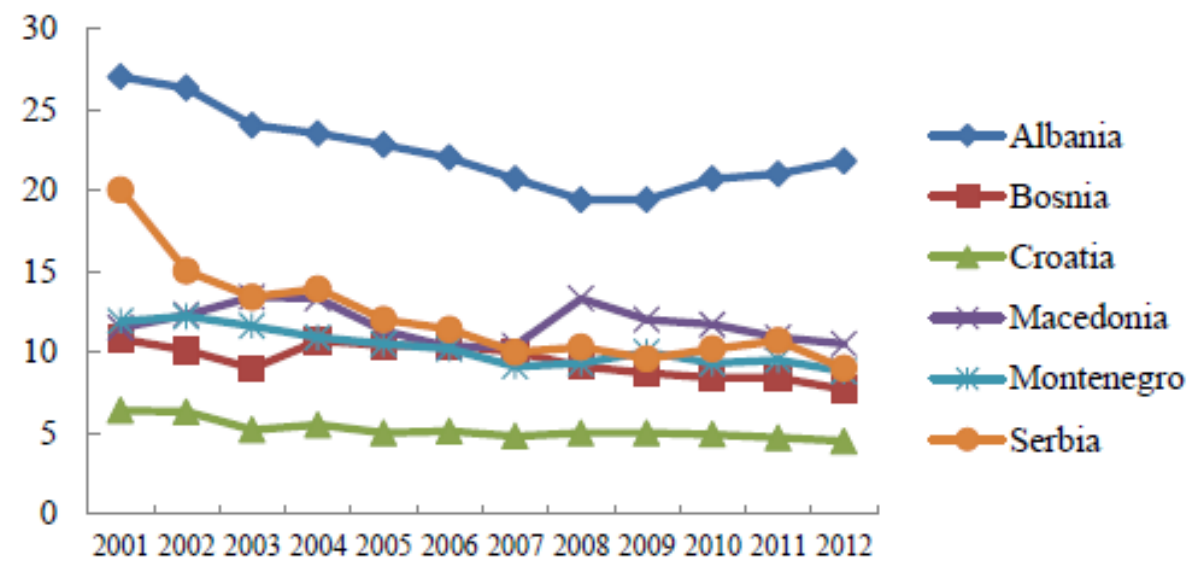

Source: World Bank.

Other Western Balkan countries are far below Albania by the share of GVA in GDP FRY Macedonia with 10\%, Serbia and Montenegro with $9 \%$, Bosnia with $8 \%$ and finally Croatia with $4 \%$. It is being expected that the trend of decrease of this indicator will continue in the future.

\section{Ranking results}

The multi-criteria analysis was conducted by using the Visual PROMETHEE software package, which has the ability to present the results graphically and, thus, to provide the more complete picture of the observed problem. As it is mentioned above, conducting the multicriteria analysis, using the PROMETHEE GAIA method, requires the definition of certain parameters. In this regard, Table 1 presents the parameters of the multi-criteria model.

As it can be seen from Table 1, all indicators should be maximized in order to investigate which one has the greatest importance of agriculture sector in the economy. Also, linear preference function, with appropriate preference threshold and indifference threshold, was applied (as the Visual PROMETHEE software suggested according to the data dispersion). Weights for all observed indicators are equal in order to perform objective analysis, without giving an advantage to any of them. All of this indicators give some important information about the importance of agriculture sector for economic development. 
Table 1. The parameters of the multi-criteria model

\begin{tabular}{|c|c|c|c|c|}
\hline Parameters & $\begin{array}{c}\text { Share of employees in } \\
\text { agriculture in total number } \\
\text { of employees }\end{array}$ & $\begin{array}{c}\text { Net Production } \\
\text { Index Number }\end{array}$ & $\begin{array}{c}\text { Balance of } \\
\text { agriculture } \\
\text { product trade } \\
(\% \text { GDP) }\end{array}$ & $\begin{array}{c}\text { Gross value } \\
\text { added, } \\
\text { agriculture (\% of } \\
\text { GDP) }\end{array}$ \\
\hline $\begin{array}{c}\text { Direction of } \\
\text { preferences }\end{array}$ & Max. & Max. & Max. & Max. \\
\hline $\begin{array}{c}\text { Preference } \\
\text { function }\end{array}$ & Linear & Linear & Linear & Linear \\
\hline $\mathrm{q}$ & 10 & 12 & 5,8 & 5,5 \\
\hline $\mathrm{p}$ & 23 & 34 & 15,5 & 11,8 \\
\hline Weights & 0.25 & 0.25 & 0.25 & 0.25 \\
\hline
\end{tabular}

Source: Author's calculations.

Using the mentioned parameters, PROMETHEE GAIA method was applied and the ranking results are shown in Figure 10. From this figure it can be concluded that the agriculture sector has the greatest importance for economic development of Albania, having in mind that it has the greatest net preference flow. Also, it should be noticed that only this country has a positive net preference flow. Albania is followed by FRY Macedonia, Bosnia and Herzegovina, Serbia, Croatia and Montenegro, whereby all these countries have negative net preference flow, thus, unfavourable position of agriculture in the economy.

Figure 10. PROMETHEE II ranking results

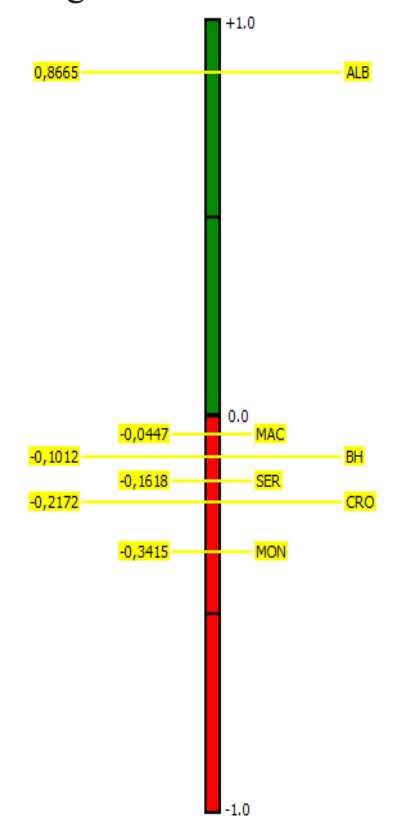

Source: Author's calculations. 
In order to realize which indicators contributed to such country ranking, the country profiles are shown in the Figure 11.

Figure 11. Country profiles

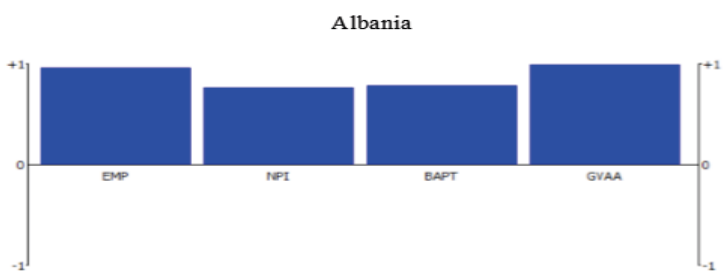

Bosnia and Herzegovina

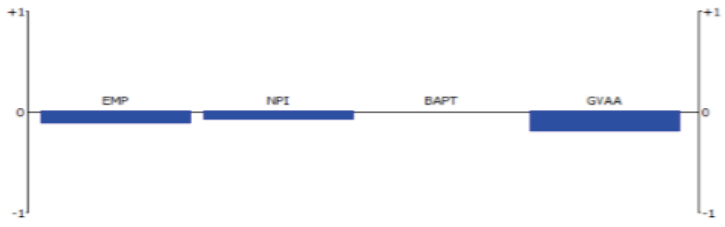

Croatia

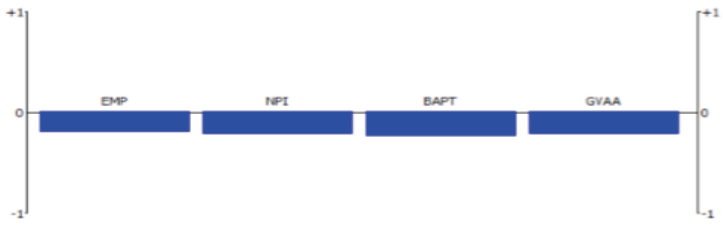

Macedonia

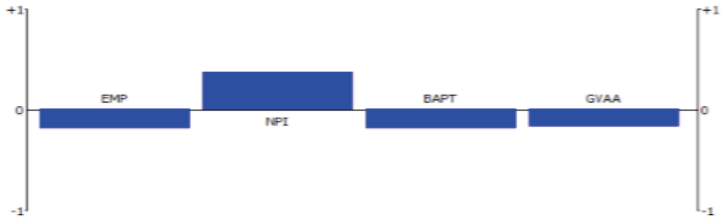

Montenegro

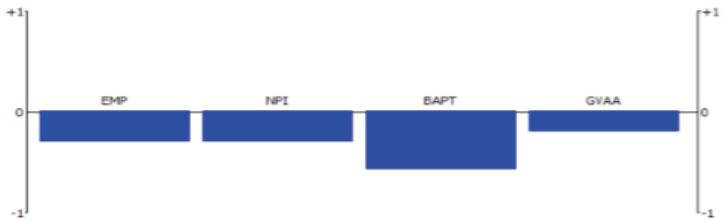

Serbia

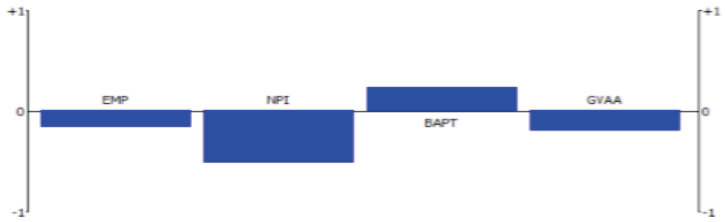

Source: Author's calculation. 
This figure indicates that Albania has significant advantage in all observed indicators over the other Western Balkan countries and that explains why this country has by far the best position. Bosnia and Herzegovina has some disadvantages in employment, net production index and gross value added in agriculture, which positioned this country in the middle of the ranking list. Croatia has relative disadvantage in all observed indicators and such state led this country to the second last position. Its second position Macedonia has deserved by significant advantage in net production index. Montenegro has the significant disadvantage in all observed indicators, especially in the agriculture products balance of trade, and that is the reason way this country has the worst position on the rankings indicating that agriculture do not contribute much to economic development of this country. Finally, Serbia reached the fourth position due to advantage in agriculture production balance of trade and disadvantage in the remaining indicators, especially in net production index.

On the basis of the ranking results it could be concluded that all countries with negative preference flow should pay much more attention to agriculture, in order to improve their own agriculture sector. This especially refers to Montenegro.

\section{Conclusion}

The changes due to transition, which began in the 90's, brought radical alterations to each field of economy and society. That was a huge challenge for the newly formed countries in Western Balkans. The previous system, based on planned economy, that had been present for decades, was supposed to be abandoned and a new model, based on market laws, was supposed to be established. Additionally, economy of scale was supposed to be replaced by rational and profitable economy. Overall, despite some positive effects, the aims of transition have not been reached. Economies of the countries in the region are in very unfavourable position nowadays. Economy and industry is recovering slowly, unemployment is becoming a general problem of the society, external and internal imbalances reached a disconcerting level, the life standard is at a very low level and the problem of poverty is becoming more pronounced.

In such circumstances agriculture, one of the most vital sectors of economy for the countries in Western Balkans, has existed and functioned for years. Additionally, during transition, agriculture had faced further problems - crucial for its development. The most important were the disclosure of large agricultural enterprises, demesne fragmentation and insufficient cooperation and integration of small farmers, internal markets became unstable and nonregulated, strengthening of monopoles and occurrence of illegal trade, import of cheap agricultural products due to liberalization of foreign trade and, finally, inadequate and insufficient financial and credit support from the government. These were, among others, some of the most important reasons for slow and difficult reforms in agriculture and the reason why market model of doing business have not been applied properly.

Applied multi criteria analysis has shown that Albania has had the greatest contribution of agriculture sector to economic development, having in mind that this country recorded significantly higher values of observed criteria. Agriculture is one of the most important drivers 
of economic development in this country. Other observed countries have had a considerably smaller contribution of agriculture to economic development. So far from Albania, according to net preference flow, Macedonia is in the second place, Bosnia and Herzegovina, Serbia, Croatia follow, while the last position on ranking list belongs to Montenegro.

Finally, it should be emphasized that it would be unrealistic to expect radical improvements in the agriculture of Western Balkans, at least in the near future. It will take considerable time and finances to change the existing state and to create basic preconditions for the application of market based economy in this field.

\section{References}

1. Agency for statistics of Bosnia and Herzegovina, available at: $\underline{h t t p: / / w w w . f z s . b a / e n g /}$ gode.htm\#AGRICULTURE

2. Behzadian, M., Kazemzadeh, R.B., Albadvi,A., Aghadasi, M. (2010): PROMETHEE: A comprehensive literature review on methodologies and applications, European Journal of Operational Research, vol. 200, no. 1, pp. 198-215.

3. Božović, Ž. Đurašković, J. (2014): The role of human factor in the development of agriculture in Montenegro, Economics of agriculture, vol. 61, no. 1, pp. 7-16.

4. Brans, J.P., Mareschal, B., Vincke, Ph. (1984): PROMETHEE: A new family of outranking methods in multi-criteria analysis, Operational Research '84, Brans, J.P. (edt.), North-Holland, Amsterdam.

5. Brans, J.P., Vincke, Ph. (1985): A preference ranking organization method: The PROMETHEE method for MCDM, Management Science, vol. 31, no. 6, pp. 647-656.

6. Croatian, http://www.dzs.hr/default e.htm

7. FAOSTAT Database, http://faostat3.fao.org/home/E

8. Fedajev, A. (2015): Improving the business environment as a factor of acceleration of economic development in transition countries (PhD thesis), University of Kragujevac, Faculty of Economics, http://nardus.mpn.gov.rs/handle/123456789/3552?show=full

9. Jolović, A., Njegovan Z., Čavlin, M. (2014): Financing of the agriculture in Serbia: state and prospects, Economics of agriculture, vol. 61, no. 1, pp. 127-137.

10. Kovacević, M. (2011): Dimenzije i uzroci neuspešne tranzicije u zemljama Zapadnog Balkana, in: Cerović, B., Uvalić, M., (edt.) Kontroverze ekonomskog razvoja u tranziciji - Srbija i Zapadni Balkan, Naučno društvo ekonomista Srbije, Ekonomski fakultet u Beogradu, Beograd.

11. Marković, P. (1989): Agrarni razvoj Jugoslavije, Ekonomika, Beograd.

12. Nikolić, R. (1999): Tržišni zakoni i razvoj poljoprivrede Jugoslavije, Ekonomika, Niš.

13. Nikolić, R. (2012): Troškovi u poslovnoj ekonomiji, Don Vas, Beograd.

14. Nikolić, R., Fedajev, A., Riznić, D. (2013): The effects of economic crisis in the Western Balkan countries, Annals of Oradea University, vol. 22, no. 2, pp. 188-194.

15. Obradović, S., Fedajev, A., Nikolić, Đ. (2012): Analysis of business environment using 
the multi-criteria approach - case of Balkan's transition countries, Serbian Journal of Management, vol. 7, no. 1, pp. 37-52.

16. Rikalović, G. (1999): Ekonomika prirodnih resursa, Biblioteka "Dr Đorđe Natošević", Inđija.

17. Savezni zavod za statistiku (1986): Jugoslavija 1945-1985. godine, Savezni zavod za statistiku, Beograd.

18. State Statistical Office of the Republic of Macedonia, available at: http://makstat. stat.gov.mk/pxweb2007bazi/Database/Census\%20of\%20Agriculture\%202007/ databasetree.asp

19. Statistical office of Montenegro - MONSTAT, available at: http://www.monstat.org/ eng/page.php?id=59\&pageid $=59$

20. Statistical Office of the Republic of Serbia, available at: http://webrzs.stat.gov. $\underline{\text { rs/WebSite/Public/PageView.aspx?pKey }=711 \& U R L=h t t p: / / p o d 2 . s t a t . g o v . r s /}$ ElektronskaBiblioteka2/Pretraga.aspx?pubType $=1$

21. Stojadinović Jovanović, S., Dašić, B. (2015): The importance offoreign direct investment for South East European countries'agriculture, Economics of agriculture, vol. 62, no. 3., pp. 661-676.

22. Stojanović, B. (2005): Tranzicija u Srbiji. Institut za evropske studije, Beograd.

23. Uvalić, M. (2011): Zašto Zapadni Balkan kasni za Centralnom i Istočnom Evropom, in: Cerović, B., Uvalić, M., (edt.) Kontroverze ekonomskog razvoja u tranziciji - Srbija i Zapadni Balkan, Naučno društvo ekonomista Srbije, Ekonomski fakultet u Beogradu, Beograd.

24. Zakić, N., Vukotić, S., Cvijanović, D. (2014): Organizational models in agriculture with special reference to small farmers, vol. 61, no. 1, pp. 225-238.

25. Zec, M., Živković, B. (1997): Tranzicija realnog i finansijskog sektora, Institut za evropske studije, Beograd. 


\title{
SEKTOR POLJOPRIVREDE U ZEMLJAMA ZAPADNOG BALKANA TOKOM PERIODA TRANZICIJE
}

\author{
Radmilo Nikolic ${ }^{5}$, Aleksandra Fedajev ${ }^{6}$, Vidoje Stefanovič , Silvana Ilic ${ }^{8}$
}

\begin{abstract}
Apstrakt
Tranzicioni procesi u zemljama Zapadnog Balkana su otpočeti tokom poslednje decade XX veka. Inisijalni rezultati tranzicije su bili ohrabrujući, ali je ovaj pozitivni trend oko vrlo brzo. Posledice raspada bivše Jugoslavije (građanski rat, sankcije UN, etnički sukobi, NATO intervencija, itd) onemogućile su sprovođenje reformi. Nakon stabilizacije političke situacije početkom XXI veka, otpočete su radikalne reforme.

Poljoprivreda predstavlja veoma značajan sector u većini od ovih privreda.Ima najveće učešće u stvaranju BDP-a, odmah nakon industrije, i najveće učešće zaposlenih u ovom sektoru u ukupnoj zaposlenosti. Međutim, tranzicioni procesi i raspad bivše Jugoslavije uzrokovali su stagnaciju u ovom sektoru u gotovo svim aspektima privređivanja. Primenjene mere $i$ aktivnosti usmerene na prevazilaženje nepovoljnog stanja u ovom sektoru nisu dale željene rezultate. Oporavak poljoprivrede je još uvek spor i suočen sa brojnim ograničenjima. U tom smishu, cilj ovog radaje analiza položaja ovog sektora u zemljama Zapadnog Balkana, primenom multikriterijumske analize.
\end{abstract}

Ključne reči: poljoprivreda, tranzicija, Zapadni Balkan, privredni razvoj, multikriterijumska analiza.

5 Redovni profesor, dr Radmilo Nikolic, Univerzitet u Beogradu, Tehnički fakultet u Boru, 19210 Bor, Ulica Vojske Jugoslavije br. 12, Srbija, Telefon: +381 63842 74 85, E-mail: rnikolic@tf.bor.ac.rs.

6 Docent, dr Aleksandra Fedajev, Univerzitet u Beogradu, Tehnički fakultet u Boru, 19210 Bor, Ulica Vojske Jugoslavije br. 12, Srbija, Telefon: +38169483 33 64, E-mail: afedajev@tt.bor.ac.rs.

7 Redovni profesor, dr Vidoje Stefanovic, Univerzitet u Nišu, Prirodno-matematički fakultet,Višegradska ulica br. 33, 18000 Niš, Srbija, Telefon: +381 6422970 77, E-mail: widojes@yahoo.com.

8 Docent, dr Silvana Ilic, Univerzitet Džon Nezbit, Fakulteta za menadžment u Zaječaru, Park šuma Kraljevica bb, 19000 Zaječar, Srbija, Telefon: +381 6550555 11, E-mail: silvana.ilic@ffmz.edu.rs. 
ECONOMICS OF

AGRICULTURE

\section{CONTENT}

1. Željko Anđelković, Aleksandra Dragin, Sanja Božić, Kristina Košić

EMOTIONAL EXHAUSTION AND JOB SATISFACTION OF TOUR GUIDES IN RURAL AREAS . . . . . . . . . . . . . . 11

2. Sanja Đukić, Danica Glavaš-Trbić, Nikola Banjac

MANAGEMENT PROBLEMS OF RURAL DEVELOPMENT IN FRUŠKA GORA . . . . . . . . . . . . . . . . . . . . 27

3. Ivana Ilić, Bojan Krstić, Sonja Jovanović

ENVIRONMENTAL PERFORMANCES OF AGRICULTURE IN THE EUROPEAN UNION COUNTRIES . . . . . . . . . . . . . 41

4. Nataša Kljajić, Jonel Subić, Zorica Sredojević

PROFITABILITY OF RASPBERRY PRODUCTION

ON HOLDINGS IN THE TERRITORY OF ARILJE. . . . . . . . . . . 57

5. Aleksandar Maksimović, Zoran Grgić, Ferhat Ćejvanović

MULTI-ATTRIBUTE ANALYSIS OF ORCHARD ACCORDING

TO THE INTEGRATED PRODUCTION CONCEPT . . . . . . . . . . 69

6. Ozrislava Milinković, Branislav Jakić, Slobodan Vuksanović,

Dragana Macura, Milica Šelmić

MULTI- CRITERIA DECISION BASED APPROACH

TO SELECTING THE TYPE OF INDUSTRIAL HALLS

USED IN FOOD INDUSTRY $\ldots \ldots \ldots \ldots$. . . . . . . . . . 81

7. Gordana Nikić, Ljubiša Stamatović, Azra Sućeska

EMOTIONAL COMPETENCIES AND PERSONALITY

TRAITS OF MANAGERS IN MODERN AGROBUSINESS. . . . . . . .97

8. Vladimir Obradović, Nemanja Karapavlović

FINANCIAL REPORTING OF COMPREHENSIVE INCOME

IN THE FOOD AND BEVERAGE SECTOR

IN THE REPUBLIC OF SERBIA . . . . . . . . . . . . . . 113 
9. Aleksandar Ostojić, Nebojša Savić, Željko Vaško

CONSUMER ATTITUDES

ON BUYING FISH IN BANJA LUKA . . . . . . . . . . . . . . . 129

10. Radivoj Prodanović, Boris Kuzman, David Jovović, Lazar Ozegović

MARKET AND TRADE OF ORGANIC FRUITS IN SERBIA $\ldots . . .141$

11. Predrag Vukadinović, Aleksandar Damnjanović, Ljiljana Dimitrijević

ANALYSIS OF THE SALES AND INCOMES BETWEEN

DIFFERENT CATEGORIES OF AGRICULTURAL PRODUCTS . . . 157

12. Jugoslav Aničić, Svetlana Vukotić, Goran Maksimović

THE POSSIBILITIES AND LIMITATIONS

OF ENTREPRENEURSHIP DEVELOPMENT

IN AGRICULTURE IN SERBIA . . . . . . . . . . . . . . 171

13. Željko Bjelajac, Marijana Dukić - Mijatović, Joko Dragojlović

FOOD SAFETY AS ONE OF THE MAIN SAFETY $P$

REOCCUPATIONS OF A MODERN MAN . . . . . . . . . . . . . 191

14. Milan Bradić, Ljiljana Kosar, Lukrecija Djeri, Svetlana Vukosav, Vuk Garača

ECO-LABELLING OF ACCOMMODATION FACILITIES

AND ITS PERCEPTION BY RURAL TOURISTS:

CASE STUDY OF VOJVODINA . . . . . . . . . . . . . . 205

15. Vaso Jegdić, Iva Škrbić, Srđan Milošević

MODELS OF ENTREPRENURSHIP DEVELOPMENT

IN RURAL TOURISM DESTINATIONS IN VOJVODINA . . . . . . . 221

16. Duško Kuzović

MUSEUM OF VERNACULAR ARCHITECTURE OF WESTERN SERBIA

- Representative curtilages of the area surrounding middle

course of the river Drina and Podgorina . . . . . . . . . . . 239

17. Branko Mihailović, Zoran Simonović, Nikola Ćurčić

AGRICULTURAL RESOURCES AND DEVELOPMENT

PRIORITIES OF THE MUNICIPALITY OF STARA PAZOVA. . . . . 259

18. Radmilo Nikolić, Aleksandra Fedajev, Vidoje Stefanović, Silvana Ilić

THE AGRICULTURE SECTOR IN WESTERN BALKANS

- SOME CHARACTERISTICS OF DEVELOPMENT. . . . . . . . . . 275

19. Vladimir Njegomir, Rajko Tepavac, Nenad Ivanišević

ALTERNATIVE SOURCES OF FINANCING

ENTREPRENEURIAL UNDERTAKINGS IN AGRICULTURE . . . 295

Economics of Agriculture, Year 64, No. 1 (1-404) 2017, Belgrade 
20. Daniela Nuševa, Kristina Mijić, Dejan Jakšić

THE PERFORMANCES OF COFFEE PROCESSORS

AND COFFEE MARKET IN THE REPUBLIC OF SERBIA . . . . . . 307

21. Svetlana Roljević Nikolić, Predrag Vuković, Biljana Grujić

MEASURES TO SUPPORT THE DEVELOPMENT OF ORGANIC

FARMING IN THE EU AND SERBIA . . . . . . . . . . . . 323

22. ŽeljkoVojinović, Vera Zelenović, DragoCvijanović

PROGRAM OF STATE SUPPORT

TO AGRICULTURAL CREDITING. . . . . . . . . . . . . . . . 339

23. Nikola Vuksanović, Dragan Tešanović, Bojana Kalenjuk,

Milijanko Portić, Marija Knežević

SOCIO-DEMOGRAPHIC CHARACTERISTICS

AS DETERMINANTS OF DIFFERENCES

IN PERCEPTION OF LOCAL GASTRONOMY . . . . . . . . . . . . 359 